\title{
INTERFERENCE OF Sorghum sudanense AND Eleucine indica IN THE SOYBeAN AND CORN Cultivation ${ }^{1}$
}

\author{
Interferência de Sorghum sudanense and Eleucine indica na Cultura da Soja e do Milho
}

\author{
RIZZARDI, M.A. ${ }^{2}$ and WANDSCHEER, A.C.D. ${ }^{2}$
}

\begin{abstract}
The natural infestations are composed of numerous species that compete for environmental resources such as water, light, nutrients and space. The objective of this study was to evaluate the interference of mixed infestations Sorghum sudanense (sudangrass) and Eleusine indica (goosegrass) in the presence of soybean and corn. The experimental design was completely randomized with four replications and the experimental units consisted of plastic pots with a volume capacity of $8 \mathrm{~L}$. The treatments were associations of plants $S$. sudanense and $E$. indica in the proportions 8:0, 6:2, 4:4,2:6 and 0:8, respectively, corresponding to $100,75,50,25$ and $0 \% S$. sudanense and the reverse for E. indica. In all treatments remained constant four soybean or corn plants per experimental unit. The variables analyzed in the weeds were shoot dry weight, root, total and height of plants. The competitive analysis was accomplished through diagrams applied to replacement series experiment and indexes of competiveness. The results indicated that E. indica was more competitive than $S$. sudanense in mixed infestations with corn. Rather, S. sudanense was more competitive than E. indica, in mixed infestations with soybean, demonstrating differences in competitiveness among the weeds.
\end{abstract}

Keywords: competition, Sorghum sudanense, Eleusine indica, competitive hability.

\begin{abstract}
RESUMO - O objetivo deste trabalho foi avaliar a interferência de infestações mistas de Sorghum sudanense (sudangrass) e Eleusine indica (goosegrass) na presença de plantas de soja e de milho. Os experimentos foram realizados em casa de vegetação, na estação de cultivo 2011/12. O delineamento adotado foi o inteiramente casualizado com quatro repetições, e as unidades experimentais consistiram de vasos plásticos com capacidade volumétrica de $8 \mathrm{~L}$. Os tratamentos foram associações de plantas de $\mathbf{S}$. sudanense e $\boldsymbol{E}$. indica nas proporções de 8:0, 6:2, 4:4, 2:6 e 0:8, respectivamente, que corresponderam a 100, 75, 50, 25 e 0\% de S. sudanense, e o inverso para E. indica. Em todos os tratamentos, mantiveram-se constantes quatro plantas de soja ou milho por unidade experimental. As variáveis analisadas nas plantas daninhas foram matéria seca da parte aérea, raiz e total, por meio de diagramas aplicados a experimentos substitutivos e indices de competitividade. Os resultados indicaram que $\boldsymbol{E}$. indica foi mais competitiva que $\mathbf{S}$. sudanense em infestações mistas com a cultura do milho. Ao contrário, S. sudanense foi mais competitiva que $\boldsymbol{E}$. indica em infestações mistas com a cultura da soja, demonstrando diferenças de competitividade entre as espécies daninhas.
\end{abstract}

Palavras-chave: -competição, Sorghum sudanense, Eleusine indica, habilidade competitiva.

\section{INTRODUCTION}

Competition may be defined as the negative interaction when individuals or plants compete for environmental resources, which leads to reduction of growth or survival of the less adapted species (Zanine $\&$ Santos, 2004; Fleck et al., 2009).

The competitive interaction between cultivations and weeds have been explored by several authors (Agostinetto et al., 2009;

Recebido para publicação em 18.6.2013 e aprovado em 15.9.2013.

1 Universidade de Passo Fundo, Passo Fundo, Rio Grande do Sul-RS, Brazil, <rizzardi@ufpfl.br>. 
Dias et al., 2010), and most studies focus on the effects of one species only. However, in nature there are different species that interact, and for this reason is becomes important to consider the combination of these effects (Rizzardi et al., 2004). Studies conducted by Bensch et al. (2003) with the cultivation of soybean and three species of Amaranthus showed a reduction in the productivity when in the presence of weeds. The most competitive was A. palmeri, followed by $A$. rudis and $A$. retroflexus. Moreover, the species that emerged along with the soybean presented greater competitive ability when compared with those that emerged later.

The productivity loss due to weed infestation depends on several factors, such as the cultivar that was used, the period of competition with the cultivation, the weeds involved, as well as the agricultural practices applied. In this context, the use of more competitive cultivars is an important aspect when handling weeds (Yirefu et al., 2012).

The substitutive series experiment is one of the most used to evaluate plants competition and it enables to verify the effects of intra or interspecific competition (Rigoli et al., 2008). In this type of experiment, the same weight of plants is used for all treatments, however, the proportion of mixed species changes (Cousens, 1991). This is an alternative for understanding the competitive effects related to density and proportion of plants in a infesting community (Christoffoleti \& Victoria filho, 1996).

The results obtained from substitution experiments are evaluated regarding the quality, by means of diagrams, or regarding the quantity, by means of mathematical expressions (Passini et al., 2003). Thus, the results obtained from substitutive experiments enable the development of more efficient strategies for handling weeds (Agostinetto et al., 2009).

Based on the possibility that cultivated plants are more competitive than weeds when both of them meet in the same proportion, this study aimed at investigating the interference of mixed infestations of Sorghum sudanense (sudangrass) and Eleusine indica (goosegrass) in the presence of soybean and corn.

\section{MATERIAL AND METHODS}

The experiments were conducted inside greenhouses, in an experimental area belonging to Centro de Extensão e Pesquisa Agropecuária (CEPAGRO) of Faculdade de Agronomia e Medicina Veterinária (FAMV), Universidade de Passo Fundo - Rio Grande do Sul, Brazil, in 2011/12.

The experimental units consisted of 25 tall plastic pots with a volume capacity of $8 \mathrm{~L}$, filled with soil from the experimental area, classified as typical Dystrophic Red Latosol. The experiments compared associations of sudangrass and goosegrass in the presence of soybean and corn, being both established together and on the same phenological stage.

The seeds used were from soybean (Glycine max - cultivar NA 5909 RG) and corn (Zea mays - hybrid DKB 240 YG) and for the weeds Sorghum sudanense (sudangrass) and Eleusine indica (goosegrass).

The experimental design was completely randomized, with four replications for each treatment; the position of the pots or experimental units was changed from time to time in order to obtain homogenous experimental conditions.

Four soybean or corn plants were placed in each experimental unit and the weeds were grafted in several proportions, based on the substitutive series experiment, keeping 12 plants per pot as total density, being eight weed plants and four cultivation plants. The treatments or proportions between $S$. sudanense and $E$. indica were, respectively: $8: 0,6: 2,4: 4,2: 6$ and $0: 8$, that is, $100,75,50$, 25 and $0 \%$ of the sudangrass, and the inverse for goosegrass.

In order to install the experimental units with both species at the same phenological stage, first of all, there was a bud break of the goosegrass seeds. Thereunto, the seeds were submitted to mechanical scarification with sandpaper (number 320) and then they were incubated in a BOD germination chamber. The temperatures and light conditions were changed to 16 hours at $20^{\circ} \mathrm{C}$ (dark) and 8 hours at $30{ }^{\circ} \mathrm{C}$ (light) for approximately four days, in accordance with Dal Magro et al. (2010). 
After the germination of the goosegrass seeds, they were transferred to polystyrene trays, with 128 spaces, filled with commercial substrate and were kept there until the emergence, approximately 20 days. After the emergence, the goosegrass seedlings were transferred to the experimental units, at the same time the soybean or corn seedlings emerged. The soybean or corn seedlings were placed in the plastic pots to germinate seven days before the goosegrass transference (soybean and corn seeds take approximately seven days to emerge). Sudangrass seeds were placed in experimental units for germination one day after the seedling of the cultivations; this species takes about six days to emerge. Thus, all species were established in experimental units at the same phenological stage.

The experiments were maintained under an irrigation system automatically controlled for two hours of irrigation daily.

As the soybean bloomed, 60 days after the emergence, and as the corn bloomed, 42 days after the emergence, the weeds were collected and the plant size, shoot, root and total dry weight were measured.

When analyzing the competitiveness of the weeds, the graphic or conventional analysis method for substitutive experiments was used (Roush et al., 1989; Cousens, 1991). Such analysis consists of making diagrams based on the relative productivity (PR) and total relative productivity (PRT), in proportions of $0,25,50,75$ and $100 \%$ of sudangrass and goosegrass plants.

The relative productivity of the analyzed variables was calculated dividing the mixed cultivation median by the monoculture median, including the plant median for each species in each experimental unit. The PRT represented the sum of relative productivities of the competitors in the respective plant proportion.

The formulas for calculating the relative and total productivities are shown as follows, according to Hoffman \& Buhler (2002): $\mathrm{PRa}=$ (p) (Amix/Amon); $\mathrm{PRb}=(1-\mathrm{p})($ Bmix/Bmon); $\mathrm{PRT}=\mathrm{PRa}+\mathrm{PRb}$, where: $\mathrm{PRa}=$ relative productivity of species " $\mathrm{A}$ " (sudangrass); $\mathrm{PRb}=$ relative productivity of species " $\mathrm{B}$ " (goosegrass); $p=$ proportion of " $A$ " in \% divided by 100; Amix $=$ value of the variable that will be analyzed (e.g.: dry weight) of "A" in mixed cultivation; Amon = value of the variable that will be analyzed of "A" in monoculture; Bmix = value of the variable that will be analyzed of " $B$ " in mixed cultivation; Bmon = value of the variable that will be analyzed of "B" in monoculture; and $\mathrm{PRT}=$ total relative productivity.

The relative indexes of competitiveness $(\mathrm{CR})$ and the relative grouping $(\mathrm{K})$ and aggressiveness (A) coefficients were calculated with $50 \%$ sudangrass and goosegrass plants. The CR represents the comparative growth of species A (sudangrass) in relation with species B (goosegrass); $\mathrm{K}$ indicates the relative dominance of one species over the other; and A shows which species is more competitive (Cousens, 1991). Species A is more competitive than species $\mathrm{B}$ when $\mathrm{CR}>1, \mathrm{Ka}>\mathrm{Kb}$ and $\mathrm{A}>0$. Species B is more competitive when $\mathrm{CR}<1$, $\mathrm{Ka}<\mathrm{Kb}$ e $\mathrm{A}<0$. The formulas for these indexes are presented as follows, in accordance with Hoffman \& Buhler (2002): CR $=((1-\mathrm{p}) / \mathrm{p})(\mathrm{PRa} /$ $\mathrm{PRb}) ; \mathrm{Ka}=((1-\mathrm{p}) / \mathrm{p})(\mathrm{PRa} /(1-\mathrm{PRa})) ; \mathrm{Kb}=((1-$ p) $/ \mathrm{p})(\mathrm{PRb} /(1-\mathrm{PRb})) ; \mathrm{e} \mathrm{A}=(\mathrm{PRa} / 2 \mathrm{p})-(\mathrm{PRb} /$ $(2(1-\mathrm{p})))$.

For the statistical analysis of relative productivity, the first calculation made was the difference between the PR (DPR) values obtained with the proportions of 25, 50 and $75 \%$ of plants and the hypothetical values with the respective proportions: $0,25,0,50$ and 0,75 . The test $t$ with $5 \%$ of overshoot was used to test the differences regarding indexes DPR, PRT, CR, $\mathrm{K}$ and $\mathrm{A}$ when compared with the hypothetical values (Hoffman \& Buhler, 2002), by means of software SAS (Statistical Analysis System version 8.0).

The hypothesis of nullity to test the differences of DPR and A considered the medians would be equal to zero $\left(\mathrm{H}_{0}=0\right)$; for $\mathrm{PRT}$ and $\mathrm{CR}$, the medians would be equal to the unity $\left(\mathrm{H}_{0}=1\right)$; and for index $\mathrm{K}$, the median of the differences between $\mathrm{Ka}$ and $\mathrm{Kb}$ would be equal to zero $\left[\mathrm{H}_{0}=(\mathrm{Ka}-\mathrm{Kb})=0\right]$.

The variables shoot dry weight, root dry weight, total dry weight and plant size were also expressed in median values by plant, which were submitted to variance analysis. 
When considered relevant by test $\mathrm{F}(\mathrm{p} \leq 0,05)$, the treatment medians were compared by Dunnett's test $(\mathrm{p} \leq 0,05)$, considering the monocultures as witnesses.

\section{RESULTS AND DISCUSSION}

The graphical analysis of the substitutive experiments with sudangrass and goosegrass plants, in the presence of corn, shows similar results for shoot, root and total dry weight (Figures 1 and 2).

The relative productivity of the sudangrass' shoot dry weight presented a relevant growth when found in greater proportion in the mixture. For the other proportions, the sudangrass presented the same productivity
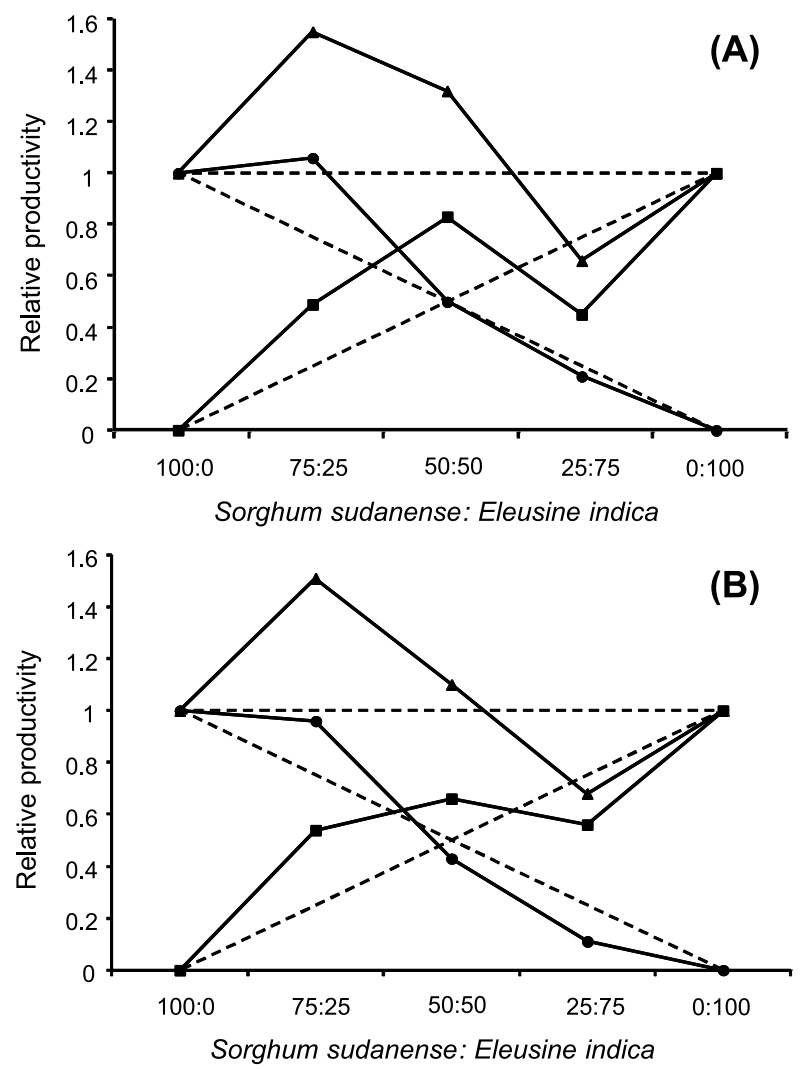

$(\bullet)$ PR of sudangrass, (•) PR of goosegrass and ( $\mathbf{\Delta}$ ) PRT. The dashed lines represent the hypothetical relative productivities whenever there is no interference between species.

Figure 1 - Relative Productivity (PR) and Total Productivity (PRT) for shoot dry weight (A) and root dry weight (B) of sudangrass (S. sudanense) and goosegrass (E. indica) plants, in the presence of corn plants. as if it were in pure state, not differing from the hypothesis that indicates absence of competition.

The goosegrass, on the other hand, was more competitive for the environmental resources and its shoot dry weight increased when found in minor or similar to the sudangrass' proportion. The relative productivity of the goosegrass' shoot dry weight reduced when found in greater proportion in the mixture, which means this species competes with itself more than with the sudangrass (Figure 1A and Table 1). A similar result was observed in Table 2, which shows the goosegrass produced more shoot dry weight when found in minor proportions compared with the sudangrass, proving the intraspecific
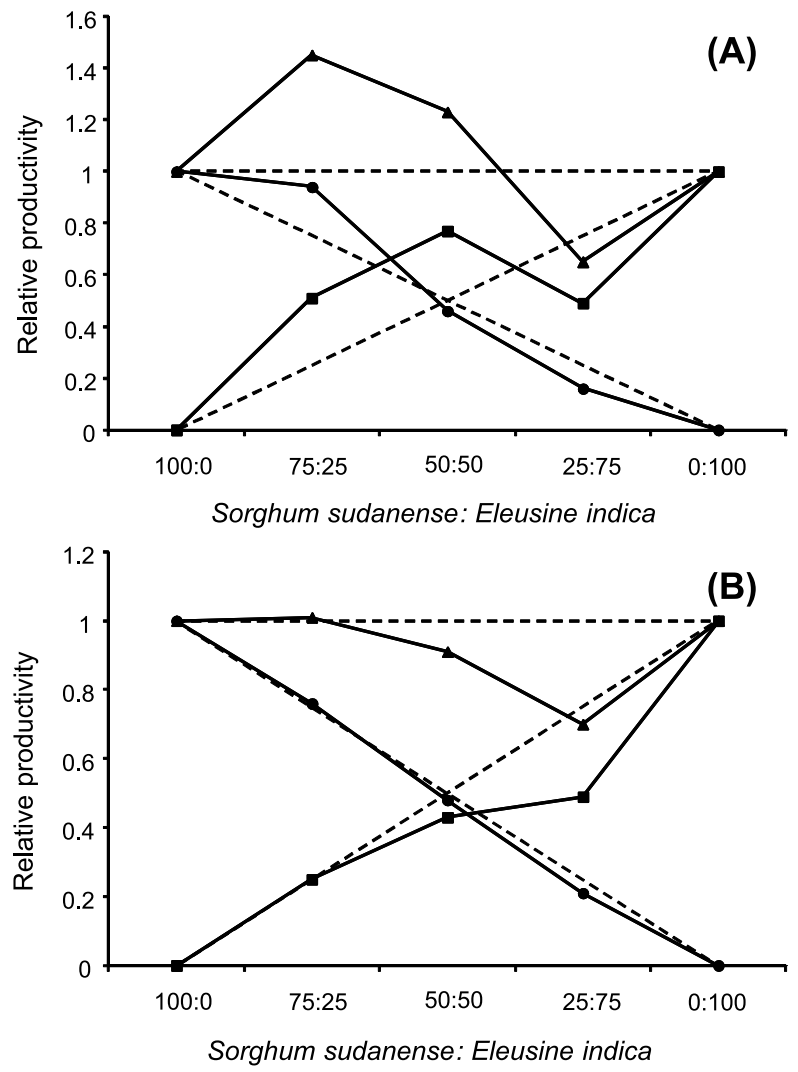

$(\bullet)$ PR of sudangrass, (•) PR of goosegrass and ( $\bullet$ ) PRT. The dashed lines represent the hypothetical relative productivities whenever there is no interference between species.

Figure 2 - Relative Productivity (PR) and Total Productivity (PRT) for total dry weight (A) and plant size (B) of sudangrass (S. sudanense) and goosegrass (E. indica) plants, in the presence of corn plants. 
Table 1 - Relative productivity differences (DPR) for the variables shoot dry weight, root dry weigh, total dry weight and plant size; and total relative productivity (PRT), in proportion to 75/25, 50/50 and 25/75 of sudangrass (S. sudanense) and goosegrass (E. indica) plants, in the presence of corn cultivation

\begin{tabular}{|c|c|c|c|}
\hline \multicolumn{4}{|c|}{ Plant proportions (sudangrass /goosegrass) } \\
\hline & $75 / 25$ & $50 / 50$ & $25 / 75$ \\
\hline \multicolumn{4}{|c|}{ MSPA $^{1 /}$} \\
\hline DPR sudangrass & $0.31( \pm 0.01)^{*}$ & $-0.001( \pm 0.03)^{\mathrm{ns}}$ & $-0.03( \pm 0.03)^{\mathrm{ns}}$ \\
\hline DPR goosegrass & $0.25( \pm 0.04) *$ & $0.33( \pm 0.01) *$ & $-0.30( \pm 0.03) *$ \\
\hline PRT & $1.55( \pm 0.04)^{*}$ & $1.33( \pm 0.03) *$ & $0.67( \pm 0.03) *$ \\
\hline \multicolumn{4}{|c|}{$\mathrm{MSR}^{2 /}$} \\
\hline DPR sudangrass & $0.22( \pm 0.07)^{\mathrm{ns}}$ & $-0.07( \pm 0.04)^{\mathrm{ns}}$ & $-0.14( \pm 0) *$ \\
\hline DPR goosegrass & $0.29( \pm 0.04) *$ & $0.16( \pm 0.02) *$ & $-0.18( \pm 0.02)^{*}$ \\
\hline PRT & $1.51( \pm 0.09) *$ & $1.10( \pm 0.05)^{\mathrm{ns}}$ & $0.68( \pm 0.02) *$ \\
\hline \multicolumn{4}{|c|}{$\mathrm{MST}^{3 /}$} \\
\hline DPR sudangrass & $0.19( \pm 0.09)^{\mathrm{ns}}$ & $-0.04( \pm 0.03)^{\mathrm{ns}}$ & $-0.09( \pm 0.02) *$ \\
\hline DPR goosegrass & $0.26( \pm 0.04) *$ & $0.27( \pm 0.01) *$ & $-0.26( \pm 0.01)^{*}$ \\
\hline PRT & $1.45( \pm 0.11) *$ & $1.23( \pm 0.04) *$ & $0.65( \pm 0.01)^{*}$ \\
\hline \multicolumn{4}{|c|}{$\mathrm{EP}^{4 /}$} \\
\hline DPR sudangrass & $0.01( \pm 0.03)^{\mathrm{ns}}$ & $-0.02( \pm 0.02)^{\mathrm{ns}}$ & $-0.04( \pm 0.02)^{\mathrm{ns}}$ \\
\hline DPR goosegrass & $0.002( \pm 0.02)^{\mathrm{ns}}$ & $-0.07( \pm 0.04)^{\mathrm{ns}}$ & $-0.26( \pm 0.04) *$ \\
\hline PRT & $1.01( \pm 0.04)^{\mathrm{ns}}$ & $0.91( \pm 0.04)^{\mathrm{ns}}$ & $0.71( \pm 0.05)^{*}$ \\
\hline
\end{tabular}

ns not relevant and $*$ relevant by the test $\mathrm{t}(\mathrm{p} \leq 0,05)$. Values between brackets represent the standard estimate error. ${ }^{1 /}$ MSPA: shoot dry weight; ${ }^{2 /}$ MSR: root dry weight; ${ }^{3 /}$ MST: total dry weight (root + shoot); ${ }^{4 /}$ EP: plant size.

Table 2 - Response of sudangrass to the interference of goosegrass 42 days after the corn emergence

\begin{tabular}{|c|c|c|c|c|c|c|}
\hline \multicolumn{7}{|c|}{ Plant proportions (sudangrass /goosegrass) } \\
\hline Variables & $100 / 0(\mathrm{~T})$ & $75 / 25$ & $50 / 50$ & $25 / 75$ & $0 / 100(\mathrm{~T})$ & $\mathrm{CV}(\%)$ \\
\hline \multicolumn{7}{|c|}{$\mathrm{MSPA}^{1 /}$} \\
\hline Sudangrass & 0.075 & 0.089 & 0.075 & 0.065 & - & 22.19 \\
\hline Goosegrass & - & $2.13 *$ & $1.94 *$ & 0.64 & 1.07 & 16.92 \\
\hline \multicolumn{7}{|c|}{$\mathrm{MSR}^{2 /}$} \\
\hline Sudangrass & 0.073 & 0.094 & 0.064 & $0.032 *$ & - & 24.08 \\
\hline Goosegrass & - & $1.16^{*}$ & 0.71 & 0.40 & 0.54 & 13.95 \\
\hline \multicolumn{7}{|c|}{$\mathrm{MST}^{3 /}$} \\
\hline Sudangrass & 0.148 & 0.185 & 0.138 & $0.097 *$ & - & 16.52 \\
\hline Goosegrass & - & $3.30 *$ & $2.65^{*}$ & 1.05 & 1.61 & 14.39 \\
\hline \multicolumn{7}{|c|}{$\mathrm{EP}^{4 /}$} \\
\hline Sudangrass & 22.8 & 23.08 & 21.75 & 19.37 & - & 13.98 \\
\hline Goosegrass & - & 37.31 & 31.97 & $24.25 *$ & 36.89 & 15.88 \\
\hline
\end{tabular}

* Median differs from the witness $(\mathrm{T})$ by the Dunnett test $(\mathrm{p} \leq 0,05)$. CV $=$ coefficient of variation. ${ }^{1 /}$ MSPA: shoot dry weight; ${ }^{2}$ MSR: root dry weight; ${ }^{3 /}$ MST: total dry weight (root + shoot); ${ }^{4 /}$ EP: plant size.

competition is more important for this species. Unlike it, the shoot dry weight values for the sudangrass in the mixture was not different from the value obtained in the monoculture.
The total relative productivity of the shoot dry weight shows that both species benefited from the association when the sudangrass was found in the same or major proportions 
compared with the goosegrass; thus, with these proportions there was no harm to any species. On the contrary, when the goosegrass was found in greater proportions, there was mutual harm to their growth, and the goosegrass was harmed due to the intraspecific competition (Figure $1 \mathrm{~A}$ and Table 1).

When analyzing the diagrams of substitution series, it is taken into consideration that if the relative productivity results in a straight line, there is no effect of one species over the other, or the species' ability to interfere over the other is equivalent; if the relative productivity results in a concave line, the growth of one or both species is harmed; and, if the relative productivity results in a convex line, the growth of one or both species is favored. Regarding the total relative productivity, if it results in a straight line, being equal to 1 , it means the competition occurs by the same environmental resources; when it is above 1 (convex), there is no competition, due to the fact that the resources supply overcome the demand or because the species have different ecological niches; and, when it is below 1 (concave), it means there is conflict, with mutual harm of the species involved (Radosevich et al., 1997).

Ovejero et al. (2007) confirmed that crabgrass biotypes that are susceptible and resistant to herbicides presented equivalent competitive abilities and similar ecological adaptation. However, the soybean was more competitive than both biotypes.

The relative productivity of the sudangrass' root dry weight suffered a relevant reduction when the goosegrass was found in major proportion in the mixture. The goosegrass presented a root dry weight when the proportions were equal or minor in the mixture when compared with the monoculture; this variable only suffered reduction when the goosegrass was found in major proportion (Figure 1B). Thus, the intraspecific competition was once again greater for the goosegrass, and the interspecific competition was more important for the sudangrass (Table 2). The total relative productivity of the root dry weight increased in the species when the goosegrass was found in minor proportion and reduced when in greater proportion. Therefore it is possible to note the goosegrass is capable of reducing its own and the sudangrass' productivity (Figure 1B and Table 1).

The competitive capacity under the soil is related with the root weight, the surface area and the enzymatic properties involved in the absorption of nutrients (Casper \& Jackson, 1997). Moreover, Christoffoleti \& Victoria Filho (1996) emphasize that the competition level among the species depends on issues related to the weed plants community, being the plant population one of the most important. Thereby, the larger the plant population, the more individuals are competing for the same environmental resources (Pitelli, 1985).

The soil occupation by the roots is of great importance for the competition, and there may be competitive difference between plants of different species in case the competitive abilities of the root system are different. For association with different species of plants, it would be ideal to arrange the plant heights in order to minimize the competition for light, as well as to use plants with different root systems, which will explore different areas of the soil (Zanine \& Santos, 2004), since the root system size usually reduces as the plant grows under competition conditions (Rizzardi et al., 2001).

The relative productivity analyses based on the proportions of both weed plants, in the presence of corn plants, showed that the sudangrass' total dry weight was significantly reduced when found in minor proportion, and the goosegrass, in major proportion in the mixture $(25 / 75)$. On the contrary, the goosegrass presented a behavior that is similar to the root and shoot dry weight, with productivity increase when in equal or minor proportion compared with the sudangrass (50/50 e 75/25) and productivity reduction when in major proportion compared with the sudangrass $(25 / 75)$. The total relative productivity showed a benefit for the species in the proportions $75 / 25$ and $50 / 50$ (sudangrass/goosegrass) and harm in the proportions 25/75 (Figure 2A and Table 1). Thus, it is possible to note again that the intraspecific competition was greater for the goosegrass, while the interspecific competition was more important for the sudangrass (Table 2). 
Several papers that aimed at evaluating the competitiveness between species showed that the more competitive one suffers more with intraspecific competition than with interspecific competition, because plants with greater competitive ability usually harms themselves due to lack of space or environmental resources (Carvalho et al., 2011; Dal Magro et al., 2011; Yamauti et al., 2011).

Reductions in the sudangrass plant size were not observed when in the presence of different proportions of goosegrass and in the presence of corn plants. However, the goosegrass plant size reduced when in major proportion in the mixture $(25 / 75)$. Hence, the total relative productivity showed that the species were harmed when the goosegrass was found in major proportion due to the effects of the intraspecific competition of this species (Figure 2B and Table 1).

By analyzing Table 2, it is possible to note there are no intra or interspecific competition effects regarding the sudangrass plant size; the proportion values are not different from the values obtained in monoculture. However, for the goosegrass, it was possible to note that the size was a little smaller when this species was in major proportion in the mixture, compared with the monoculture. This means the intraspecific competition is more important than the interspecific. For Roush et al. (1989), the intra and interspecific interaction are key-factors in the competitive process among plants.

Klingaman \& Oliver (1994) observed that the plant density of Amaranthus palmeri had little effect over the soybean size. Meantime, Dias-Filho (2006) points out that the difference in the species size is one of the characteristics that better relates with the competition, for the plant will be competitively superior if it holds a capacity to capture the environment resources faster than the plant neighbors. This author shows that the plant size growth depends mainly on the energy supplied by reservoirs, as well as the photosynthetic capacity and the individual structure of the plant.

The graphical analysis of the relative productivity values obtained from the mixture of soybean, sudangrass and goosegrass plants showed that the species competed for the resources, and the results varied in accordance with the proportion of the species (Figures 3 and 4).

The diagrams obtained from substitutive experiments with sudangrass and goosegrass plants evidenced the competitive superiority of the sudangrass, which maintained its productivity when in major proportion and exceeded the productivity expectation when found in equal or minor proportions compared with the goosegrass.

The goosegrass, on the other hand, had its shoot dry weight reduced when in equal or minor proportion compared with the sudangrass; it only produced above the expected when found in major proportion in the mixture. The total relative productivity of the shoot dry weight for both species indicated a loss in proportions $75 / 25$ and 50/50 (sudangrass/goosegrass) and a growth benefit for both species in proportions 25/75. This shows that the sudangrass presented as a more aggressive competitor when compared with the goosegrass whenever the species were cultivated in the presence of soybean (Figure $3 \mathrm{~A}$ and Table 3).

Considering the root dry weight, there were some competitiveness differences, depending on the proportion of the weed species involved. In this variable, the sudangrass produced above the expected when found in equal proportions compared with the goosegrass and maintained its productivity in the other proportions. The opposite happened with the goosegrass, which had its root dry weight reduced when the sudangrass was found in major proportion in the mixture and maintained the productivity in the other proportions. The total relative productivity indicated that the species competed for the same resources; however, there was loss when the sudangrass was found in major proportion (Figure 3B and Table 3).

When comparing both weed plant species, it was possible to note a reduction of the goosegrass' total dry weight when it was found in equal or minor proportions compared with the sudangrass. When found in major proportions, it produced above the expected.

Planta Daninha, Viçosa-MG, v. 32, n. 1, p. 19-30, 2014 

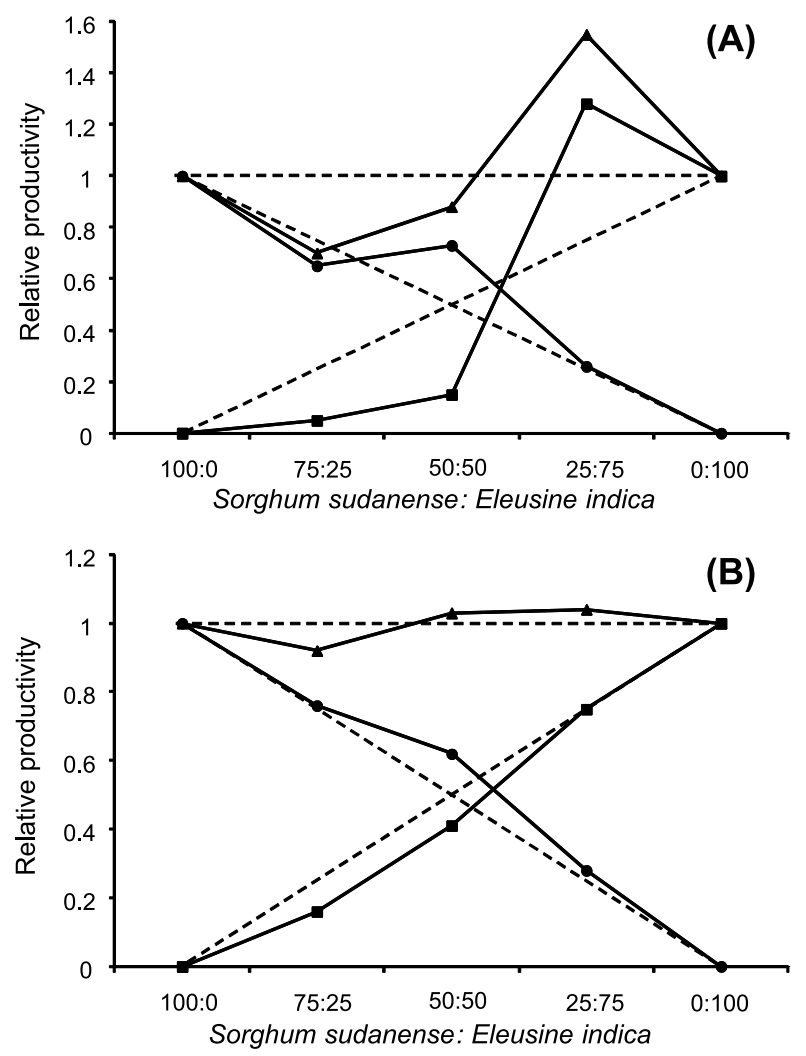

$(\bullet)$ PR of sudangrass, (•) PR of goosegrass and ( $\mathbf{\Delta}$ ) PRT. The dashed lines represent the hypothetical relative productivities whenever there is no interference between species.

Figure 3 - Relative Productivity (PR) and Total Productivity (PRT) for shoot dry weight (A) and root dry weight (B) of sudangrass (S. sudanense) and goosegrass (E. indica) plants, in the presence of soybean plants.

The sudangrass also presented production above the expected when found in equal proportions in the mixture. The total relative productivity for the total dry weight indicated a loss of growth in the species when the sudangrass was found in major proportions and a benefit when the goosegrass was found in major proportions, indicating that the sudangrass was a more aggressive competitor (Figure 4A and Table 3).

Oliveira \& Schreiner (1987) emphasize that the competition among plants may exist in many ways, so that the productivity of a species may increase or reduce in relation with their monoculture.

Regarding the plant size, a relevant reduction of the goosegrass was observed when
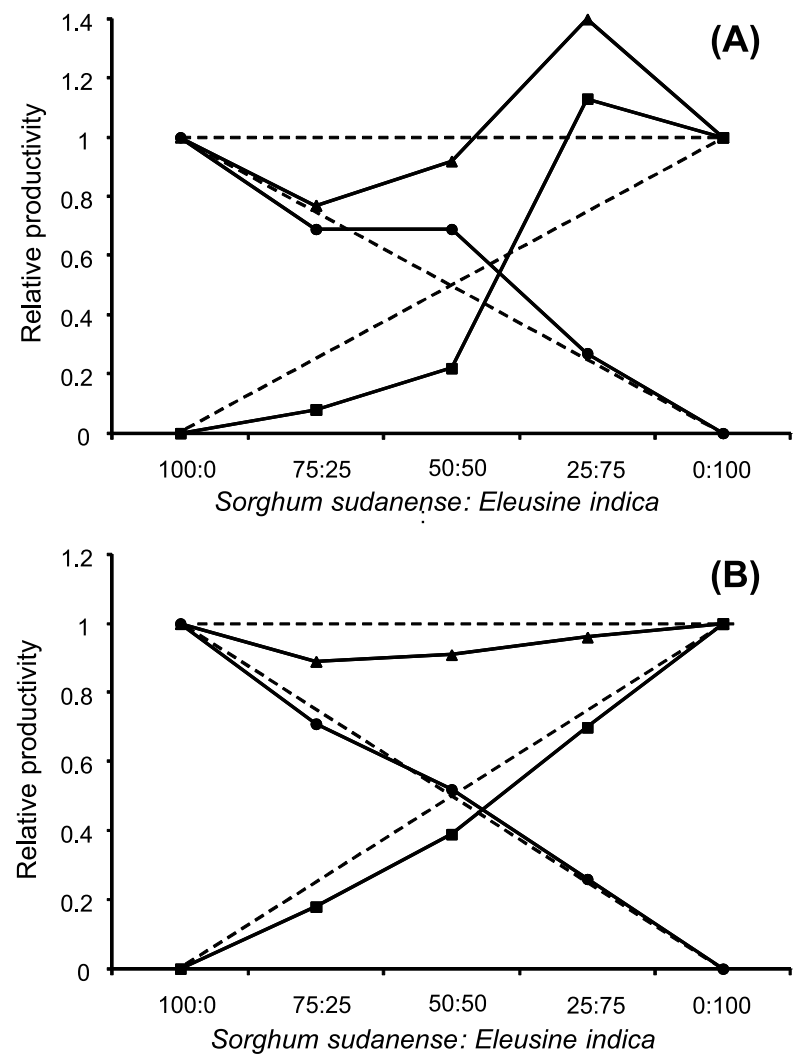

$(\bullet)$ PR of sudangrass, (•) PR of goosegrass and ( $(\boldsymbol{\bullet})$ PRT. The dashed lines represent the hypothetical relative productivities whenever there is no interference between species.

Figure 4 - Relative Productivity (PR) and Total Productivity (PRT) for total dry weight (A) and plant size (B) of sudangrass (S. sudanense) and goosegrass (E. indica) plants, in the presence of soybean plants.

found in equal or minor proportions compared with the sudangrass. The sudangrass, on the other hand, maintained its productivity and it was not influenced by the association with the competitor. The total relative productivity of the plant size indicated loss of growth in the proportions $75 / 25$ and $50 / 50$ of sudangrass and goosegrass plants, respectively, showing one more time that the sudangrass was more competitive (Figure 4B and Table 3).

Bianchi et al. (2006) report that the plant size and the number and length of branches are among the characteristics that provide the soybean cultivation with a greater ability to compete with weed plants. Yet, the shoot dry weight, the soil coverage and the grain production are more important characteristics. 
Table 3 - Relative productivity differences (DPR) for the variables shoot dry weight, root dry weigh, total dry weight and plant size; and total relative productivity (PRT), in proportion to 75/25, 50/50 and 25/75 of sudangrass (S. sudanense) and goosegrass (E. indica) plants, in the presence of soybean cultivation

\begin{tabular}{|c|c|c|c|}
\hline \multicolumn{4}{|c|}{ Plant proportions (sudangrass /goosegrass) } \\
\hline & $75 / 25$ & $50 / 50$ & $25 / 75$ \\
\hline \multicolumn{4}{|c|}{ MSPA $^{1 /}$} \\
\hline DPR sudangrass & $-0.10( \pm 0.03)^{\mathrm{ns}}$ & $0.23( \pm 0.01) *$ & $0.01( \pm 0) *$ \\
\hline DPR goosegrass & $-0.20( \pm 0) *$ & $-0.35( \pm 0.02) *$ & $0.54( \pm 0.01)^{*}$ \\
\hline PRT & $0.70( \pm 0.03) *$ & $0.88( \pm 0.02) *$ & $1.55( \pm 0.02)^{*}$ \\
\hline \multicolumn{4}{|l|}{$\mathrm{MSR}^{2 /}$} \\
\hline DPR sudangrass & $0.01( \pm 0.03)^{\mathrm{ns}}$ & $0.12( \pm 0.04) *$ & $0.03( \pm 0.02)^{\mathrm{ns}}$ \\
\hline DPR goosegrass & $-0.09( \pm 0.02) *$ & $-0.09( \pm 0.04)^{\mathrm{ns}}$ & $0.01( \pm 0.19)^{\mathrm{ns}}$ \\
\hline PRT & $0.92( \pm 0.02) *$ & $1.03( \pm 0.06)^{\mathrm{ns}}$ & $1.04( \pm 0.20)^{\mathrm{ns}}$ \\
\hline \multicolumn{4}{|c|}{$\mathrm{MST}^{3 /}$} \\
\hline DPR sudangrass & $-0.06( \pm 0.03)^{\mathrm{ns}}$ & $0.19( \pm 0.02)^{*}$ & $0.02( \pm 0.01)^{\mathrm{ns}}$ \\
\hline DPR goosegrass & $-0.16( \pm 0.01) *$ & $-0.27( \pm 0.02)^{*}$ & $0.38( \pm 0.05)^{*}$ \\
\hline PRT & $0.77( \pm 0.03)^{*}$ & $0.92( \pm 0.03)^{\mathrm{ns}}$ & $1.40( \pm 0.05)^{*}$ \\
\hline \multicolumn{4}{|c|}{$\mathrm{EP}^{4 /}$} \\
\hline DPR sudangrass & $-0.03( \pm 0.01)^{\mathrm{ns}}$ & $0.03( \pm 0.02)^{\mathrm{ns}}$ & $0.01( \pm 0.01)^{\mathrm{ns}}$ \\
\hline DPR goosegrass & $-0.07( \pm 0.01) *$ & $-0.11( \pm 0.01) *$ & $-0.05( \pm 0.04)^{\mathrm{ns}}$ \\
\hline PRT & $0.89( \pm 0.01)^{*}$ & $0.91( \pm 0.01)^{*}$ & $0.96( \pm 0.05)^{\mathrm{ns}}$ \\
\hline
\end{tabular}

${ }^{n s}$ not relevant and * relevant by the test $\mathrm{t}(\mathrm{p} \leq 0,05)$. Values between brackets represent the standard estimate error. ${ }^{1 /}$ MSPA: shoot dry weight; ${ }^{2 /}$ MSR: root dry weight; ${ }^{3 /}$ MST: total dry weight (root + shoot); ${ }^{4 /}$ EP: plant size.

By verifying the response of sudangrass to the interference with the goosegrass in the presence of soybean, it was possible to note the sudangrass suffered the effects of intraspecific competition, considering the shoot dry weight and the total dry weight; the values for these variables were significantly higher whenever the species was found in minor proportion, in comparison with the monoculture. The contrary was observed for the goosegrass, which had reductions in this variable when found in minor proportions in the mixture, indicating that the interspecific competition is more important for this species. Regarding the sudangrass' root dry weight and plant size, the values were not different from those obtained with the monoculture. The goosegrass, in comparison with its monoculture, showed significantly lower plant size values when found in minor proportions in the mixture, which suggests the prevalence of interspecific competition (Table 4).

Whenever there is competition among the species in the environment, one or more resources that are necessary for the growth are limited to fulfill the needs of the plants involved, thus, there may be an intra or interspecific competition (Radosevich et al., 1997). In the association between soybean and alexandergrass plants there was conflict, due to the fact that no species was competitively dominant over the other; for both species, the intraspecific competition was more important than the interspecific (Agostinetto et al., 2009). Radosevich et al. (1997) highlight that, in general, the intraspecific competition between cultivated plants is more severe than the interspecific competition of weed plants over cultures.

By the results obtained from this study, the goosegrass proved to be a more aggressive competitor when compared with the sudangrass whenever both species competed in the presence of corn, taking into consideration the shoot, root and total dry weight variables, thus, $\mathrm{CR}<1, \mathrm{Ka}<\mathrm{Kb}$ e $\mathrm{A}<0$. Regarding the plant size variable, there was no difference between the species (Table 5). 
Table 4 - Response of sudangrass to the interference of goosegrass 42 days after the soybean emergence

\begin{tabular}{|c|c|c|c|c|c|c|}
\hline \multicolumn{7}{|c|}{ Plant proportions (sudangrass /goosegrass) } \\
\hline Variables & $100 / 0(\mathrm{~T})$ & $75 / 25$ & $50 / 50$ & $25 / 75$ & $0 / 100(\mathrm{~T})$ & CV $(\%)$ \\
\hline \multicolumn{7}{|c|}{$\mathrm{MSPA}^{1 /}$} \\
\hline Sudangrass & 3.28 & $2.84 *$ & $4.80 *$ & 3.45 & - & 5.54 \\
\hline Goosegrass & - & $0.25 *$ & $0.35 *$ & $2.05^{*}$ & 1.20 & 7.92 \\
\hline \multicolumn{7}{|c|}{$\mathrm{MSR}^{2 /}$} \\
\hline Sudangrass & 1.77 & 1.78 & 2.19 & 2.01 & - & 11.90 \\
\hline Goosegrass & - & 0.33 & 0.41 & 0.50 & 0.50 & 32.39 \\
\hline \multicolumn{7}{|c|}{$\mathrm{MST}^{3 /}$} \\
\hline Sudangrass & 5.06 & 4.63 & $7.0 *$ & 5.47 & - & 5.51 \\
\hline Goosegrass & - & $0.58 *$ & $0.76^{*}$ & $2.56^{*}$ & 1.69 & 10.12 \\
\hline \multicolumn{7}{|c|}{$\mathrm{EP}^{4 /}$} \\
\hline Sudangrass & 99.65 & 95.29 & 104.81 & 105.00 & - & 8.78 \\
\hline Goosegrass & - & $33.87 *$ & $37.31 *$ & 44.83 & 48.03 & 9.02 \\
\hline
\end{tabular}

* Median differs from the witness $(\mathrm{T})$ by the Dunnett test $(\mathrm{p} \leq 0,05)$. CV $=$ coefficient of variation. $\stackrel{1 /}{ }$ MSPA: shoot dry weight; $\stackrel{2}{2}$ MSR: root dry weight; ${ }^{3}$ MST: total dry weight (root + shoot); ${ }^{4 /}$ EP: plant size.

Table 5 - Indexes of competitiveness between the sudangrass and the goosegrass, in the presence of corn and soybean plants, expressed by relative competitiveness (CR), relative grouping (K) and aggressiveness (A) coefficients

\begin{tabular}{|c|c|c|c|c|}
\hline \multicolumn{5}{|c|}{ In the presence of corn plants } \\
\hline Variables & $\mathrm{CR}$ & $\mathrm{K}_{\mathrm{s}=\text { sudangrass }}$ & $\mathrm{K}_{\mathrm{c}=\text { goosegrass }}$ & $\mathrm{A}$ \\
\hline $\mathrm{MSPA}^{\underline{1} /}$ & $0.60( \pm 0.03) *$ & $1.00( \pm 0.11)^{*}$ & $4.86( \pm 0.33) *$ & $-0.33( \pm 0.03) *$ \\
\hline $\mathrm{MSR}^{2 /}$ & $0.65( \pm 0.05) *$ & $0.78( \pm 0.10) *$ & $2.00( \pm 0.17) *$ & $-0.23( \pm 0.03) *$ \\
\hline $\mathrm{MST}^{3 /}$ & $0.59( \pm 0.04) *$ & $0.86( \pm 0.11) *$ & $3.35( \pm 0.13) *$ & $-0.31( \pm 0.03) *$ \\
\hline $\mathrm{EP}^{4 /}$ & $1.14( \pm 0.15)^{\mathrm{ns}}$ & $0.91( \pm 0.07)^{\mathrm{ns}}$ & $0.79( \pm 0.14)^{\mathrm{ns}}$ & $0.04( \pm 0.06)^{\mathrm{ns}}$ \\
\hline \multicolumn{5}{|c|}{ In the presence of soybean plants } \\
\hline $\mathrm{MSPA}^{1 /}$ & $5.14( \pm 0.51) *$ & $2.73( \pm 0.12) *$ & $0.17( \pm 0.02) *$ & $0.58( \pm 0.01) *$ \\
\hline $\mathrm{MSR}^{2 /}$ & $1.53( \pm 0.15)^{*}$ & $1.69( \pm 0.23) *$ & $0.72( \pm 0.11) *$ & $0.21( \pm 0.04) *$ \\
\hline $\mathrm{MST}^{3 /}$ & $3.13( \pm 0.25) *$ & $2.27( \pm 0.17)^{*}$ & $0.29( \pm 0.03) *$ & $0.47( \pm 0.02) *$ \\
\hline $\mathrm{EP}^{4 /}$ & $1.36( \pm 0.08) *$ & $1.11( \pm 0.07)^{*}$ & $0.63( \pm 0.03) *$ & $0.14( \pm 0.03) *$ \\
\hline
\end{tabular}

${ }_{\mathrm{ns}}$ not relevant and $*$ relevant by the test $\mathrm{t}(\mathrm{p} \leq 0,05)$. Values between brackets represent the standard estimate error. ${ }^{1 /}$ MSPA: shoot dry weight; ${ }^{2 /}$ MSR: root dry weight; ${ }^{3 /}$ MST: total dry weight (root + shoot); 늘 EP: plant size.

In the competition between sudangrass and goosegrass plants in the presence of soybean, the competitiveness indexes (CR, K e A) showed that, for equal proportions of plants, the sudangrass was more competitive than the goosegrass in all variables considered, being $\mathrm{CR}>1, \mathrm{Ka}>\mathrm{Kb}$ and $\mathrm{A}>0$ (Table 5).

Rigoli et al. (2008) did not observe any difference regarding the relative competitiveness index, showing that the radish did not grow more than the wheat.
However, the relevance of indexes $\mathrm{K}$ and $\mathrm{A}$ evidenced the dominance of the radish over the wheat.

Pitelli (1985) emphasizes that the specific composition of the weed plant community is an extremely important factor for defining the competition, because the species involved have different growing habits, as well as different nutritional and environmental resources requirements. For this author, in communities with several individuals, none of the organisms grow in accordance with their 
genetic potential, but in accordance with the amount of resources they are able to exploit from the environment, considering the intense competition they are submitted to.

The characterization of the competitive capacity of soybean and corn cultures provides important conditions for the genetic improvement and strategies development in the integrated wield of weed plants (Fleck et al., 2006).

Based on the data obtained in this study, it is possible to conclude that E. indica was more competitive than S. sudanense in infestations mixed with the corn culture. In opposition, S. sudanense was more competitive than E. indica in infestations mixed with the soybean culture, which shows competitiveness difference between the weed species.

\section{ACKNOWLEDGEMENTS}

The authors are thankful to the Brazilian Council of Scientific and Technological Development (CNPq) and the Coordination for the Improvement of Higher Education Personnel (CAPES).

\section{LITERATURE CITADA}

AGOSTINETTO, D. et al. Competitividade relativa da soja em convivência com papuã (Brachiaria plantaginea). Sci. Agric., v. 10, n. 3, p. 185-190, 2009.

BENSCH, C. N. et al. Interference of redroot pigweed (Amaranthus retroflexus), Palmer amaranth (A. palmeri), and common waterhemp (A. rudis) in soybean. Weed Sci., v. 51, n. 1, p. 37-43, 2003.

BIANCHI, M. A. et al. Características de plantas de soja que conferem habilidade competitiva com plantas daninhas. Bragantia, v. 65, n. 4, p. 623-632, 2006.

CARVALHO, L. B. et al. Effects of plant density and proportion on the interaction between wheat with alexandergrass plants. Bragantia, v. 70, n. 1, p. 40-45, 2011.

CASPER, B. B.; JACKSON, R. B. Plant competition underground. Ann. Rev. Ecol. System., v. 28, n. 1, p. 545-570, 1997.

CHRISTOFFOLETI, P. J.; VICTORIA FILHO, R. Efeitos da densidade e proporção de plantas de milho (Zea mays L.) e caruru (Amaranthus retroflexus L.) em competição. Planta Daninha, v. 14, n. 1, p. 42-47, 1996.
COUSENS, R. Aspects of the design and interpretation of competition (interference) experiments. Weed Technol., v. 5, n. 3, p. 664-673, 1991.

DAL MAGRO, T. et al. Supressão da dormência de sementes de capim pé de galinha (Eleusine indica). In: CONGRESSO BRASILEIRO DA CIÊNCIA DAS PLANTAS DANINHAS, 27., 2010, Ribeirão Preto. Anais... Ribeirão Preto: 2010. p. 1177-1181.

DAL MAGRO, T. et al. Habilidade competitiva entre biótipos de Cyperus difformis L. resistente ou suscetível a herbicidas inibidores de ALS e destes com arroz irrigado. Bragantia, v. 70, n. 2, p. 294-301, 2011.

DIAS, A. C. R. et al. Competitiveness of Alexandergrass or Bengal Dayflower with soybean. Planta Daninha, v. 28, n. 3, p. 515-522, 2010.

DIAS-FILHO, M. B. Competição e sucessão vegetal em pastagens. Belém: Embrapa Amazônia Oriental, 2006. (Documentos Online, 240).

FLECK, N. G. et al. Interferência de Raphanus sativus sobre cultivares de soja durante a fase vegetativa de desenvolvimento da cultura. Planta Daninha, v. 24, n. 3, p. 425-434, 2006.

FLECK, N. G. et al. Associação de características de planta em cultivares de aveia com habilidade competitiva. Planta Daninha, v. 27, n. 2, p. 211-220, 2009.

HOFFMAN, M. L.; BUHLER, D. D. Utilizing Sorghum as a functional model of crop-weed competition. I. Establishing a competitive hierarchy. Weed Sci., v. 50, n. 4, p. 466-472, 2002.

KLINGAMAN, T. E.; OLIVER, L. R. Palmer Amaranth (Amaranthus palmeri) interference in soybeans (Glycine max). Weed Sci., v. 42, n. 4, p. 523-527, 1994.

OLIVEIRA, E. B.; SCHREINER, H. G. Caracterização e análise estatística de experimentos de agrossilvicultura. B. Pesq. Flor., v. 1, n. 15, p. 19-40, 1987.

OVEJERO, R. F. L. et al. Crescimento e competitividade de biótipos de capim-colchão resistente e suscetível aos herbicidas inibidores da acetil coenzima A carboxilase. Pesq. Agropec. Bras., v. 42, n. 1, p. 1-8, 2007.

PASSINI, T. et al. Competitiveness of the common-bean plant relative to the weed alexandergrass [Brachiaria plantaginea (Link) Hitch.]. Sci. Agric., v. 60, n. 2, p. 259-268, 2003.

PITELLI, R. A. Interferência de plantas daninhas em culturas agrícolas. Inf. Agropec., v. 11, n. 129, p. 16-25, 1985.

Planta Daninha, Viçosa-MG, v. 32, n. 1, p. 19-30, 2014 
RADOSEVICH, S. R. et al. Plant-plant associations. In: RADOSEVICH, S. R. et al. Ecology of weeds and invasive plants: relationship to agriculture and natural resource management. 3.ed. New Jersey: John Wiley \& Sons, 1997. $454 \mathrm{p}$.

RIGOLI, R. P. et al. Habilidade competitiva relativa do trigo (Triticum aestivum) em convivência com azevém (Lolium multiflorum) ou nabo (Raphanus raphanistrum). Planta Daninha, v. 26, n. 1, p. 93-100, 2008.

RIZZARDI, M. A. et al. Competição por recursos do solo entre ervas daninhas e culturas. Ci. Rural, v. 31, n. 4, p. 707-714, 2001.

RIZZARDI, M. A. et al. Interferência de populações de Euphorbia heterophylla e Ipomoea ramosissima isoladas ou em misturas sobre a cultura de soja. Planta Daninha, v. 22, n. 1, p. 29-34, 2004.
ROUSH, M. L. et al. A comparison of methods for measuring effects of density and proportion in plant competition experiments. Weed Sci., v. 37, n. 2, p. 268-275, 1989.

YAMAUTI, M. S. et al. Interações competitivas de triticale (Triticum turgidosecale) e nabiça (Raphanus raphanistrum) em função da população e proporção de plantas. Planta Daninha, v. 29, n. 1, p. 129-135, 2011.

YIREFU, F. et al. Competitive ability of sugarcane (Saccharum ofûcinarum L.) cultivars to weed interference in sugarcane plantations of Ethiopia. Crop Protec., v. 32, n. 1, p. 138-143, 2012.

ZANINE, A. M.; SANTOS, E. M. Competição entre espécies de plantas - uma revisão. R. FZVA, v. 11, n. 1, p. 10-30, 2004. 